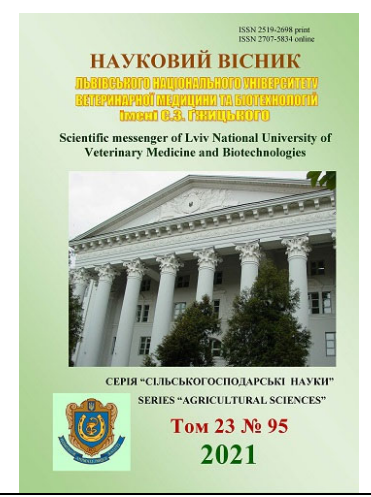

Науковий вісник Дьвівського національного університету ветеринарної медицини та біотехнодогій імені С.3. Гжицького. Серія: Сільськогосподарські науки

\author{
Scientific Messenger of Lviv National University \\ of Veterinary Medicine and Biotechnologies. \\ Series: Agricultural sciences
}

doi: 10.32718/nvlvet-a9521

https://nvlvet.com.ua/index.php/agriculture

UDC 681.1:636.084.52

\title{
Influence of conditions of keeping bee families in wintering on their productivity
}

\author{
V. Hrabarivska \\ Vinnytsia National Agrarian University, Vinnytsia, Ukraine
}

Article info

Received 29.06.2021

Received in revised form 29.07.2021

Accepted 30.07.2021

Vinnytsia National Agrarian University, Soniachna Str.,3, Vinnytsia, 21000, Ukraine. Tel.: +38-097-702-83-40 E-mail: grabarivska777@gmail.com
Hrabarivska, V. (2021). Influence of conditions of keeping bee families in wintering on their productivity. Scientific Messenger of Lviv National University of Veterinary Medicine and Biotechnologies. Series: Agricultural sciences, 23(95), 141-146. doi: 10.32718/nvlvet-a9521

Creating favorable conditions for the development of bee colonies, adherence to technological techniques and processes are of great importance in increasing productivity. The article highlights the results of research on the impact of increased subframe space during the wintering of bee colonies on their further development and productivity. In the course of the research, bee colonies were evaluated on the basis of a set of economically useful traits. For research, 2 groups of bee colonies were identified, 10 in each, equivalent in strength and food security, with young fertile queens bred in the same year. The formation of experimental groups took into account the strength of bee colonies, the number of closed brood, the age of the queens, the availability of feed (honey and perga), and the quality of nest cells. These indicators in the experimental groups were almost the same. When preparing bee colonies for winter, the frames in the families of the control group were in the center of the hive, removed the top insulation and unscrewed the sheets by 5-7 sm in the experimental group performed the same actions as in the control winters substituted empty store extensions, thus increasing the subframe space. During the research, honey and wax productivity, strength of families in different periods of the active season and winter hardiness were determined. It was found that bees kept in the hives with increased subframe space, in which $76.1 \%$ less plague was detected, compared with the control group, tolerate wintering well. These families are developing more intensively in the spring and summer period - the advantage in strength was $25.8 \%$ in April, $31.4 \%$ in May, and $31.6 \%$ in June. And further they show higher honey and wax productivity by 24.9 and $32.1 \%$, respectively.

Key words: bees, subframe space, honey productivity, wax productivity, winter hardiness, family strength.

\section{Вплив умов утримання бджолиних сімей взимку на їхню продуктивність}

\author{
В. Л. Грабарівська
}

Вінницький національний аграрний університет, м. Вінниця, Україна

Створення сприятливих умов для розвитку бджолиних сімей, дотримання технологічних прийомів $і$ прочесів мають велике значення у підвищенні продуктивності. У статті висвітлені результати досліджень щзодо впливу збільщеного підрамкового простору під час зимівлі бджолиних сімей на їх подальший розвиток та продуктивність. У ході досліджень проводили оцінку бджолиних сімей за комплексом господарсько-корисних ознак. Для проведення досліджень виділили 2 групи бджолиних сімей по 10 у кожній, рівноцінних за силою і кормозабезпеченістю, з молодими плідними матками, виведеними в цььому ж рочі. При формуванні піддослідних груп враховували силу бджолиних сімей, кількість закритого розплоду, вік маток, наявність кормів (меду і перги) та якість стільників гнізда. Перераховані показники у піддослідних групах були практично однаковими. При підготовці бджолиних сімей до зимівлі рамки у сім'ях контрольної групи складали в центрі вулика, знімали верхнє утеплення і відвертали полотнинки на 5-7 см. У дослідній групі проводили ті ж дї̈, щуо й у контрольній, але додатково під гніздовий корпус на період зимівлі підставляли порожні магазинні надставки, збільшивши тим самим підрамковий простір. Протягом досліджень визначали медо - та воскопродуктивність, силу сімей у різні періоди активного сезону та зимостійкість. Встановлено, щчо добре переносять зимівлю бджоли, шьо утримувались у вуликах зі збільшеним підрамковим простором, в яких менше виявлено підмору на 76,1 \% порівняно з контроль- 
ною групою. Ці сім'ї інтенсивніше розвиваються у весняно-літній період - перевага за силою у квітні була на 25,8 \%, травні - на 31,4\%, у червні - на 31,6 \%. I в подальшому вони показують вищу медову та воскову продуктивність відповідно на 24,9 та 32,1 \%.

Ключові слова: бджоли, підрамковий простір, медопродуктивність, воскопродуктивність, зимостійкість, сила сім ’̈.

\section{ВстуII}

Основою успіху бджільництва $є$ своєчасне і професійне виконання всіх операцій з утримання бджолиної сім'ї. Тому необхідно створювати сприятливі умови для їхнього розвитку, дотримуватись усіх гігієнічних вимог при утриманні бджіл у різні пори року, стежити за інноваціями в цій галузі, а отже - забезпечувати продуктивність та оптимальний потенціал бджолиної сім'ї. У підвищенні продуктивності бджолиних сімей велике значення має створення сприятливих умов, дотримання технологічних прийомів i процесів, що відбуваються під час розвитку бджолиних сімей, роботи під час медозбору, ведення племінної роботи та багатьох інших чинників. Виробництво меду та продуктивність бджолиних сімей збільшуватиметься завдяки впровадженню нових технологій, сучаснішому обладнанню у догляді за бджолами тощо.

Зовнішній вплив погодно-кліматичних умов знижує життєздатність бджолиної сім'ї протягом року. Незважаючи на те, що у процесі еволюції бджоли адаптувались до несприятливих умов зовнішнього середовища, все ж таки зимовий період відрізняється низкою особливостей та може негативно на них вплинути. Зимівля $\epsilon$ найважчим періодом у житті бджіл. Від умов їхнього проживання взимку залежатиме виживання бджіл та сила сім'ї навесні, а отже - i кількість отриманої продукції.

Успішне протікання зимівлі в основному залежить від сили сім'ї та ефективності витрачання кормів. У сильній сім'ї кормів витрачається менше для підтримки температури в клубі. До кінця зимівлі такі сім’ї не зазнають значних втрат робочих бджіл, не забруднюють гніздо екскрементами, в таких сім'ях виведення першого весняного покоління перезимованими бджолами не викликає їхньої масової загибелі. Навесні сильні сім'ї швидше розвиваються, вирощують більшу кількість розплоду і забезпечують високий медозбір влітку.

Безпалий І. Ф. та інші дослідники розробили біотехнологічний прийом із тимчасової ізоляції наповнених стільників, для підвищення продуктивного медозбору. У своїх дослідженнях під час взятку з білої акації відбирались із гнізда стільники з незрілим медом для підвищення медопродуктивності сімей. На їхнє місце підставляли порожні стільники (Bezpalyi et al., 2021).

Зимостійкість бджіл значною мірою залежить від численних факторів, серед яких правильне розташування кормів у стільниках, оптимальні умови вологості та температури. Кормові запаси у гнізді бджіл розміщують різними способами: однобічним, двобічним, “бородою" та комбінованим. Залежно від сили сім’ї бджолам залишають таку кількість стільників, щоб вони їх покривали. Відповідно до сили бджолиних сімей та кліматичних умов формуються запаси зимового корму, у середньому по 2 кг меду на вуличку бджіл. У кожному вулику обов'язково потрібно мати 2-3 стільника 3 пергою, що містяться на краях вулика (Dombrovskyi et al., 2002; Markov, 2007).

Сприятливі умови для виникнення й поширення захворювань складаються при підвищеній вологості у гнізді під час зимівлі бджіл. У вуликах буде сухо та бджоли краще себе почуватимуть при зимівлі з великим підрамковим простором. Тоді бджоли матимуть можливість об'єднатися у суцільний клуб частково під стільниками, що дасть змогу контактувати з маткою бджолам з усіх вуличок клуба (Razanova, 2018). Повітряною подушкою може слугувати порожній корпус, піддашок та ін., що ставлять під корпус із бджолами. При такій зимівлі бджолині сім’ї майже на $40 \%$ мають більше розплоду навесні та на 30 \% перед головним медозбором порівняно з сім'ями, що зимували без повітряної подушки (Repka, 2014; Razanova, 2020).

Від системи, конструкції і типу вулика залежать продуктивність і розвиток бджолиних сімей. Вулик добирають, враховуючи природні умови, особливості медозбору та біологічні особливості порід бджіл (Razanov et al., 2010; Khamid, 2014; Khamid et al., 2021). Багатокорпусна система вулика повніше відповідає біології бджолиної сім'ї. Головна його особливість полягає у тому, що в міру зростання сім’ї та накопичення меду обсяг вулика можна необмежено збільшувати додаванням нових корпусів. Це дає можливість вирощувати сильні сім’ї і підтримувати їх у робочому стані. Комплектація корпусів рамками відбувається в зимовий період, коли немає основних робіт (Halimov, 2019; Razanova \& Skoromna, 2020).

При зниженні температури нижче ніж $5{ }^{\circ} \mathrm{C}$ у навколишньому середовищі, бджолині сім’ї переміщують у зимівник. Він має бути сухим, з витяжною вентиляцією, $з$ температурою повітря від $-3{ }^{\circ} \mathrm{C}$ до $+3{ }^{\circ} \mathrm{C}$, відносною вологістю не вище 75-85 \% (Kochetov, 2011; Vodin, 2017). Для зимівлі на волі потрібно мати у 2-2,5 раза більше корму та досконало володіти системою утримання бджіл взимку (Markov, 2007).

Ковальський Ю. В. та інші у своїх дослідженнях встановили, що фізіологічні процеси у бджіл пов'язані 3 тепловиділенням у вигляді підвищеної активності функціонування м'язів грудного відділу комах. Ними встановлено, що для фізіологічно повноцінних, сильних, здорових бджолосімей умови зовнішнього мікроклімату суттєвого впливу на перебіг зимівлі не мають. Можна успішно утримувати такі бджолосім’ї у зимівнику і надворі. Але сім’ї невеликої сили період зимівлі переносять значно краще у спеціалізованих зимівниках або спеціально облаштованих приміщеннях із дотриманням оптимальних умов мікроклімату (Kovalskyi et al., 2017).

Економічні збитки від поганої зимівлі бджіл приблизно дорівнюють вартості всього одержуваного від них меду. Великий відхід або сильне ослаблення 
бджіл сімей в зимовий період може звести нанівець всю напружену роботу пасічника протягом усього весняно-літнього попереднього сезону (Papchenko, 2013).

У зв'язку з цим вивчення способів зимівлі бджолиних сімей в сучасних природно-кліматичних умовах становить науковий і практичний інтерес, тому $є$ актуальним завданням.

Метою роботи є вивчення впливу збільшення підрамкового простору під час зимівлі бджолиних сімей на їхній розвиток та продуктивність.

\section{Матеріал і методи досліджень}

У ході досліджень проводили оцінку бджолиних сімей за комплексом господарсько-корисних ознак. Для проведення досліджень виділили 2 групи бджолиних сімей по 10 у кожній, рівноцінних за силою і кормозабезпеченістю, з молодими плідними матками, виведеними в цьому ж році. При формуванні піддослідних груп враховували силу бджолиних сімей, кількість закритого розплоду, вік маток, наявність кормів (меду і перги) та якість стільників гнізда. Перераховані показники у піддослідних групах були практично однаковими. Піддослідні бджолині сім’ї утримувалися у вуликах-лежаках на 20 рамках розміром 435×300 мм. При підготовці бджолиних сімей до зимівлі рамки у сім'ях контрольної групи складали в центрі вулика, знімали верхнє утеплення і відвертали полотнинки на 5-7 см. У дослідній групі проводили ті ж дії, що й у контрольній, але додатково під гніздовий корпус на період зимівлі підставляли порожні магазинні надставки, збільшивши тим самим підрамковий простір.

Кількість меду визначали шляхом зважування рамок до і після відкачування меду. Воскопродуктивність визначали за кількістю стільників, відбудованих на вощині однією сім'єю бджіл і в середньому по кожній групі.

Зимостійкість оцінювали шляхом порівняння даних осінньої і весняної ревізій. При цьому враховували: масу підмору, запаси корму і опроношеність гнізда на момент весняної ревізії.

Силу бджолиних сімей визначали 3 рази протягом сезону: навесні під час головної весняної ревізії, у травні та перед початком головного медозбору.

\section{Результати та їх обговорення}

За даними спостережень за першим очисним вильотом бджіл із вулика виявлено, що сім’ї дослідної групи активніші, раніше здійснюють обліт, не залишають на передній стінці вулика калових мас. На відміну від сімей дослідної групи, сім’ї контрольної групи забруднювали передню стінку вулика.

Результати проведення весняної ревізії бджіл дослідної та контрольної груп наведені в таблиці 1.

Таблиця 1

Весняна ревізія бджолиних сімей

\begin{tabular}{lcc}
\hline \multicolumn{1}{c}{ Показник } & & Група \\
\cline { 2 - 3 } & контрольна & дослідна \\
Сила сім’ї, вуличок & $6,2 \pm 0,24$ & $7,8 \pm 0,30$ \\
Запаси корму, кг & $7,3 \pm 0,33$ & $8,7 \pm 0,37$ \\
Кількість розплоду, рамок & $2,7 \pm 0,01$ & $3,6 \pm 0,08$ \\
Забрудненість рамок каловими масами, балів & 3 & Відсутня \\
Підмор, г & $154,6 \pm 2,11$ & $87,8 \pm 1,53$ \\
\hline
\end{tabular}

Якщо сила сімей під час осінньої підготовки до зимівлі у піддослідних групах була однаковою, то весною перевага була за дослідною групою у вуликах зі збільшеним підрамковим простором. Сім’ї даної групи зберегли свою силу, яка була вищою за показник у контрольній групі на 25,8 \% (табл. 1).

Огляд бджолиних сімей після зимівлі під час весняної ревізії показав, що в дослідній групі у гніздах залишилося більше кормових запасів, менше підмору бджіл та більше розплоду. Бджоли за зиму в дослідній групі витратили кормів на 19,2 \% менше, ніж у контрольній групі.

На період весняної ревізії у дослідній групі було більше розплоду на 33,3 \%. В цій групі також відсутня забрудненість рамок калом і незначна кількість підмору. При огляді гнізд бджолиних сімей виявлено, що гніздо у дослідних групах чисте, без слідів калу та цвілі. У контрольній групі, де сім’ї зимували у вуликах без додаткового підрамкового простору, забрудненість рамок каловими масами становила 3 бали. За наявністю підмору сім’ї дослідної групи перевершували на 76,1 \% контрольну групу.

Чим інтенсивніше розвивається бджолина сім'я навесні, тим вона краще буде використовувати медозбір. Особливості росту бджолиних сімей вивчали після проведеної весняної ревізії на пасіці.

На рисунку 1 показано подальший розвиток бджолиних сімей.

За всіма періодами розвитку бджолині сім'ї дослідної групи, які взимку утримували у вуликах зі збільшеним підрамковим простором, перевершували контрольну групу. Так, перевага за силою у дослідних сім'ях над контрольними у квітні була на 25,8 \%, у травні - на 31,4 \%, у червні - на 31,6 \%.

Інтенсивність росту у сім'ях дослідної групи з квітня по червень становила $261,5 \%$, а у контрольній 250,0 \%. За весь період досліду за цим показником у весняно-літній період перевага у дослідній групі бджолиних сімей становила в середньому 11,5 \%. 


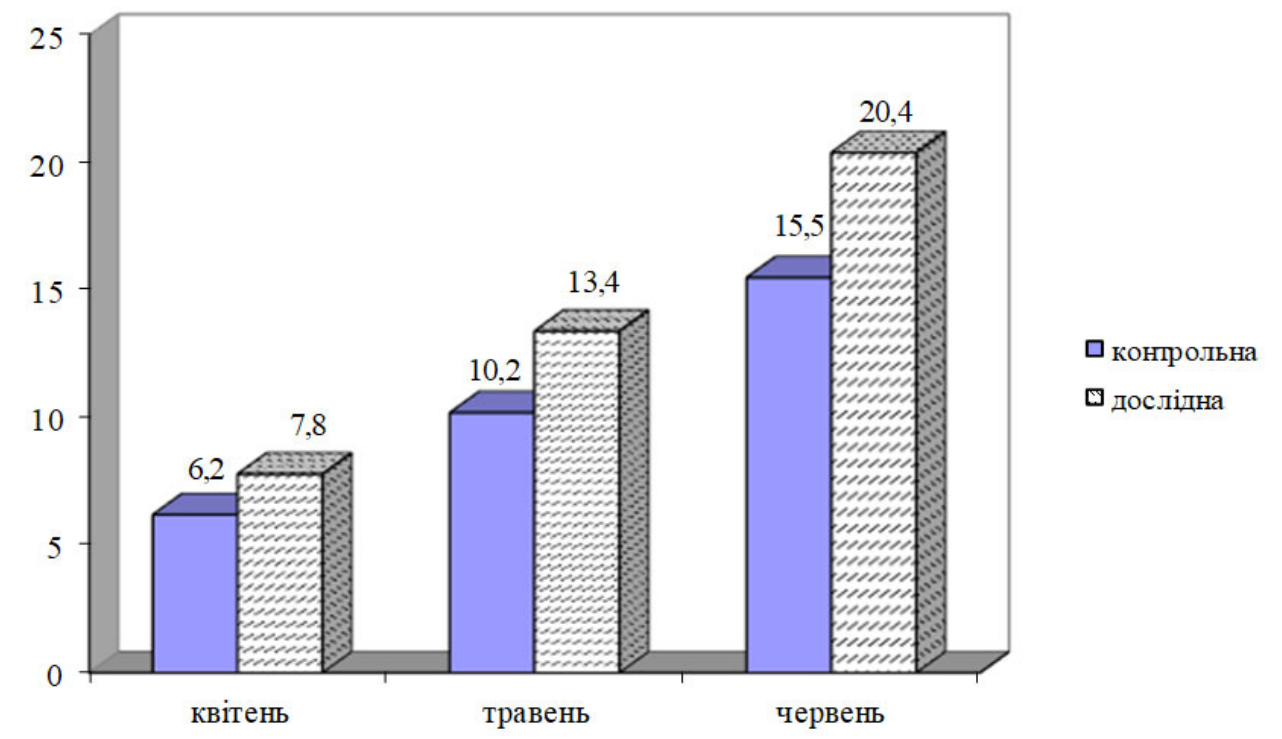

Рис. 1. Розвиток бджолиних сімей у весняний період, вуличок

Досвід роботи бджолярів переконливо свідчить, що забезпечувати результативні збори меду можуть лише сильні сім’і. Кількість зібраного бджолиною сім'єю меду за певний час залежить від багатьох чинників, серед яких сила сім’ї, наявність кормових запасів у гніздах, медовий ресурс місцевості, порода бджіл, погодні умови.

У кінці головного медозбору, за результатами отриманих даних при відкачуванні меду, проведено оцінку медопродуктивності бджолиних сімей, що показано на рисунку 2.

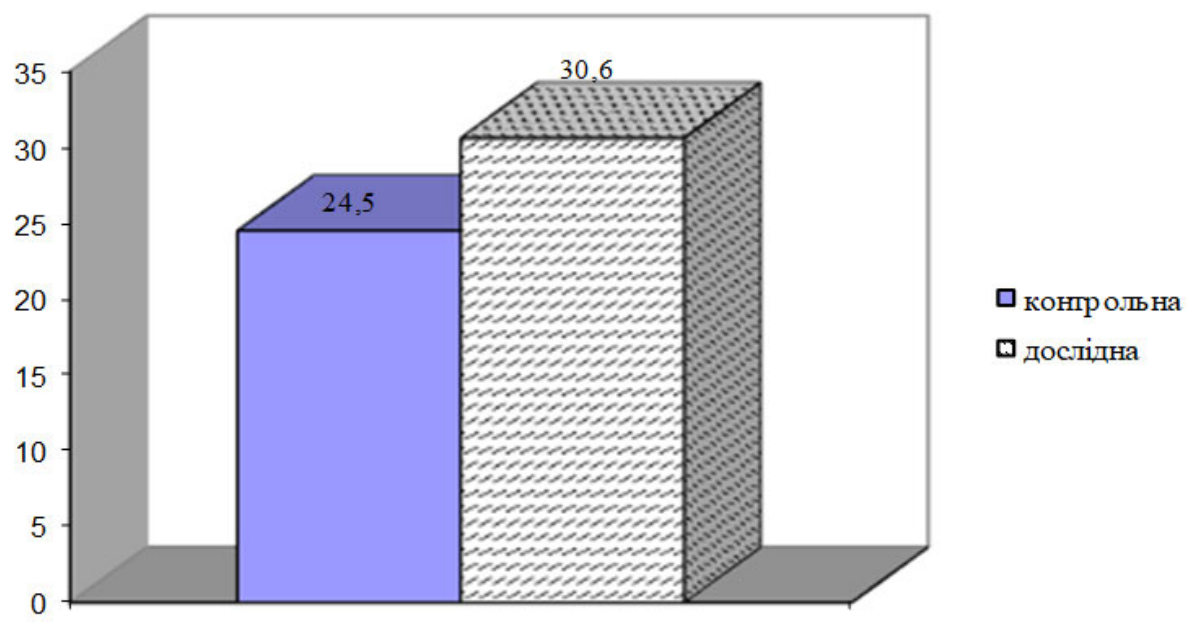

Рис. 2. Медопродуктивність бджолиних сімей, кг

Дослідна група сімей, яких взимку утримували у вуликах зі збільшеним підрамковим простором, порівняно з контрольною значно більше дала меду. Перевага склала у середньому на сім'ю 6,1 кг, або 24,9 \%.

Від надходження у бджолине гніздо нектару залежать воскобудівельна продуктивність бджіл й відповідно кількість відбудованих стільників, на відбудову яких витрачається багато корму.
За результатами проведених досліджень виявлено, що вищі показники щодо воскової продуктивності були у сімей дослідної групи (рис. 3).

Сім'ї, які утримувались у вуликах зі збільшеним підрамковим простором, відбудували більшу кількість стільників і від них отримано на 0,9 кг, або на 32,1 \% більше воску, порівняно з контролем. 


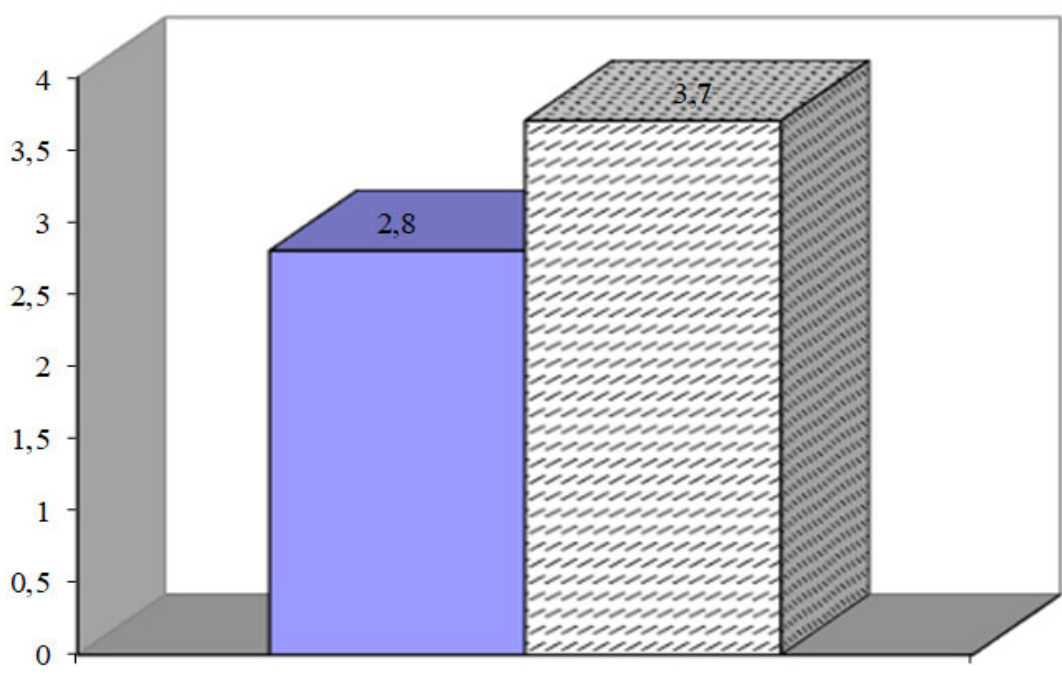

$\mathbf{\square}_{\text {контрольна }}$

- дослідна

Рис. 3. Воскова продуктивність бджолиних сімей, кг

\section{Висновки}

Таким чином, аналізуючи проведені дослідження, можна зробити висновок, що бджоли добре переносять зимівлю зі збільшеним підрамковим простором, інтенсивніше розвиваються у весняно-літній період, нарощують більшу кількість бджіл і в подальшому показали вищу медову та воскову продуктивність відповідно на 24,9 та 32,1\%.

\section{References}

Bezpalyi, I. F., Postoienko, V. O., Merzlov, S. V., \& Postoienko, D. M. (2021). Rozroblennia biotekhnolohichnoho pryiomu z tymchasovoi izoliatsii napovnenykh stilnykiv dlia pidvyshchennia produktyvnosti medozboru ta yakosti bdzholynoho medu. [Development of a biotechnological method for temporary isolation of filled honeycombs to increase the productivity of honey collection and the quality of bee honey]. Tekhnolohiia vyrobnytstva i pererobky produktsii tvarynnytstva, 1, 137-142 (in Ukrainian).

Dombrovskyi, O. B., Yarchuk, B. M., Tyrsin, R. V., Korniienko, L. M., \& Korniienko, L. E. (2002). Praktykum $\mathrm{z}$ pytan bdzhilnytstva ta khvorob bdzhil. [Workshop on beekeeping and bee diseases]. Bila Tserkva, 49-76 (in Ukrainian).

Halimov, S. M. (2019). Tekhnolohiia vyrobnytstva produktsii bdzhilnytstva. [Technology of beekeeping production]. Mykolaiv: MNA (in Ukrainian).

Khamid, K. O. (2014). Porivnialna kharakterystyka produktyvnykh yakostei bdzhil ukrainskoi stepovoi porody pry riznykh umovakh zymivli. [Comparative characteristics of productive qualities of bees of Ukrainian steppe breed under different wintering conditions]. Ahrarnyi visnyk Prychornomoria, 71(2), 7174 (in Ukrainian).

Khamid, K., Pushkar, T., Salachykly, A., \& Kytaieva, A. (2021). Survival of bees in different types of winter. Agrarian Bulletin of the Black Sea Littoral, 100, 109 116. doi: 10.37000/abbsl.2021.100.19.
Kochetov, A. S. (2011). Organizatsiya zimovki pchel, ispolzuemyih $\mathrm{v}$ teplitsah. [Organization of wintering of bees used in greenhouses]. Pchelovodstvo, 9, 13-14 (in Russian).

Kovalskyi, Yu. V., Fedorovych, V. V., \& Druzhbiak, A. Y. (2017). Vplyv temperaturnoho rezhymu zymivli ta syly bdzholynykh simei na intensyvnist metabolichnykh protsesiv robochykh osobyn. [Influence of wintering temperature and strength of bee colonies on the intensity of metabolic processes of workers]. Ahrarna nauka ta kharchovi tekhnolohii, 5(99), 74-79 (in Ukrainian).

Markov, V. I. (2007). Rost i razvitie pchelinoy semi v techenii goda. [Growth and development of a bee colony throughout the year]. Pchelovodstvo, 9, 10-12 (in Russian).

Papchenko, O. V. (2013). Rozvytok bdzholynykh simei za riznykh sposobiv yikh utrymannia $\mathrm{v}$ umovakh produktyvnykh medozboriv. [Development of bee colonies in different ways of keeping them in the conditions of productive honey harvests]. Visnyk Luhanskoho natsionalnoho ahrarnoho universytetu, 18(2(31)), 119-123 (in Ukrainian).

Razanov, S. F., Bezpalyi, I. F., Bala, V. I., \& Donchenko, T. A. (2010). Tekhnolohiia vyrobnytstva produktsii bdzhilnytstva. [Technology of beekeeping production]. K.: Ahrarna osvita (in Ukrainian).

Razanova, E. P. (2020). Rezultatyi zimovki i vesennee razvitie pchelinyih semey pri vliyanii skarmlivaniya probiotika. [Wintering results and spring development of bee colonies under the influence of probiotic feeding]. Veterinarnyiy zhurnal Belarusi, 2, 135-138 (in Russian).

Razanova, O. P. (2018). Vliyanie apivita na zhiznesposobnost pchelinyih semey v period zimovki. [Influence of apivit on the viability of bee colonies during the wintering period]. Ştiinţa agricola, 2, 111-114. URL: https://sa.uasm.md/index.php?journal=sa\&page=article \&op=view\&path $\% 5 \mathrm{~B} \% 5 \mathrm{D}=627$ (in Russian).

Razanova, O. P. (2019). Rasshirenie kormovoy bazyi pchelovodstva dlya povyisheniya proizvoditelnosti pchelinyih semey. [Expansion of the beekeeping fod- 
der base to increase the productivity of bee colonies]. Sbornik nauchnyih trudov "Aktualnyie voprosyi pererabotki myasnogo i molochnogo syirya", 224-229. URL: http://repository.vsau.org/getfile.php/21149.pdf (in Russian).

Razanova, O. P., \& Skoromna, O. I. (2020). Tekhnolohiia vyrobnytstva produktsii bdzhilnytstva: Navchalnyi posibnyk. [Technology of beekeeping production: Textbook]. Vinnytsia (in Ukrainian).

Razanova, O., Kucheriavy, V., Tsaruk, L., Lotka, H., \& Novgorodska, N. (2021). Productive flight activity of bees in the active period in the conditions of vinnytsia region. Journal of Animal Behaviour and Biometeorology, 9(4), 2138. doi: 10.31893/jabb.21038.

Repka, V. (2014). Pidhotovka do holovnoho medozboru. [Preparation for the main medical collection.]. Pasichnyk, 8(125), 6-8 (in Ukrainian).

Vodin, I. A. (2017). Vliyanie usloviy zimovki pchel na ih produktivnost. [Influence of wintering conditions of bees on their productivity]. Molodoy uchenyiy, 9, 4548 (in Russian). 